\title{
Use of faba beans (Vicia faba L.) in diets of laying hens
}

\author{
Erja Koivunen ${ }^{1 *}$, Petra Tuunainen ${ }^{1}$, Eija Valkonen ${ }^{1,2}$, Laila Rossow ${ }^{3}$, Jarmo Valaja ${ }^{1,4}$ \\ ${ }^{1}$ MTT Agrifood Research Finland, Animal Production Research, 31600 Jokioinen, Finland \\ ${ }^{2}$ Current address: Hankkija Oy, P.O. Box 390, 05801 Hyvinkää, Finland \\ ${ }^{3}$ Finnish Food Safety Authority Evira, 00790 Helsinki, Finland \\ ${ }^{4}$ Current address: Department of Agricultural Sciences, P.O. Box 28, University of Helsinki, 00014, Finland \\ e-mail: erja.koivunen@mtt.fi
}

\begin{abstract}
The study was conducted to evaluate an appropriate inclusion level of locally produced unprocessed or expander-processed coloured flowered faba bean (FB) (cv. 'Kontu') seeds in diets for laying hens. Egg production and egg quality variables were determined with 560 hens (Lohmann Selected Leghorn, LSL Classic) in a 40-week continued experiment. The hens were fed one of the five diets containing soybean meal as the main protein source. A diet without FB was served as a control diet. Both unprocessed and expander-processed FB was tested either in proportions of $50 \mathrm{~g} \mathrm{~kg}^{-1}$ or $100 \mathrm{~g} \mathrm{~kg}^{-1}$ in the diet. Faba bean inclusion (control vs. FB diets) had no effect on the egg production rate, egg mass production, feed consumption, or feed conversion ratio, but it decreased egg weight $(p<0.05)$. Dietary FB inclusion tended to increase the mortality of the hens $(p<0.10)$. Faba bean processing had no effects on egg production parameters or hen mortality. Daily egg mass production decreased and feed conversion ratio increased when FB proportion increased (from 50 to $100 \mathrm{~g} \mathrm{~kg}^{-1}, p<0.05$ ). Faba bean inclusion had no effects on egg exterior quality. It can be concluded that $50 \mathrm{~g} \mathrm{~kg}^{-1}$ of the FB studied (cv. 'Kontu') can be used in the diets of laying hens (LSL Classic) without negative effects on production performance or livability.
\end{abstract}

Key words: egg production, faba bean, feed processing, health, laying hen

\section{Introduction}

Soybean is the most commonly used protein source in poultry diets in Europe (Laudadio and Tufarelli 2010). Because soybean meal (SBM) is a by-product of oil extraction from soybeans, the cost of SBM depends on the price of agricultural commodities on the world market. These prices are influenced by changes in economic growth, consumer product preferences, and weather conditions (Jezierny et al. 2010). Soybean prices are highly volatile, but an upward trend is detectable. Furthermore, the supply of non-genetically modified soybeans is diminishing and thus the relating premiums are increasing. As a result, there is an interest to maximise the use of other- and especially locally produced protein sources. Faba bean (Vicia faba L.) (FB) is a protein-rich legume and adapted to most climatic areas of Europe. FB's low fertiliser requirements and its capacity to return nitrogen to the soil make it an ecosystem-serviced crop (Jensen et al. 2010). Faba bean is a good source of lysine, but sulphur containing amino acids methionine and cysteine are present at low levels in the protein of FB (Gatel 1994). In addition, the digestibilities of these amino acids have often been found to be low in FB (Brufay et al. 1998). The use of FB in diets for non-ruminants is restricted due to its content of anti-nutritional factors (ANF) (Crépon et al. 2010). Dehulling and heat treatment are recommended to allow a maximum inclusion level of FB in laying hen diets (Marquardt et al. 1973). Unlike most of the ANF, vicine and convicine $(\mathrm{V}+\mathrm{C})$ located in the cotyledons in FB are heat-stable (Crépon et al. 2010), and therefore they cannot be easily removed through technological or chemical processes (Dvořák et al. 2006). Crépon et al. (2010) summarised, that the use of FB with a high V+C content cannot exceed $70 \mathrm{~g} \mathrm{~kg}^{-1}$ of the diet, but it is possible to include FB at up to $200 \mathrm{~g} \mathrm{~kg}^{-1}$ if the cultivar used has a low V+C content. There is a need to evaluate the optimal inclusion levels of locally cultivated FB cultivars in the diets of laying hens.

The objective of this study was to find an appropriate inclusion level of locally produced unprocessed or expander-processed coloured flowered FB seeds (cv. 'Kontu') in diets of laying hens. The study further aimed to examine the effects of FB on the livability of the hens, and the hens' egg quality variables. In addition, the content of $V+C$ present in studied unprocessed or expander-processed FB cultivar was studied. 


\title{
Materials and methods \\ Experimental animals and treatments
}

\begin{abstract}
A total of 560 39-week-old Leghorn chicken (Lohmann Selected Leghorn, LSL Classic) were assigned to 5 different dietary treatments. A diet based on cereal and SBM served as the control diet (Table 1). Both unprocessed and

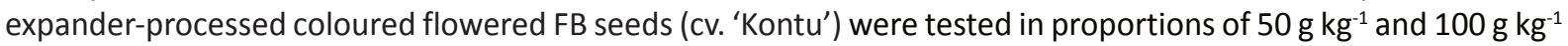
of feed. The hens were housed in enriched (furnished) cages (TAPE, Triotec Oy, Koski TL, Finland). The dimensions of cages were $120 \mathrm{~cm} \times 50 \mathrm{~cm} \times 48 \mathrm{~cm}$ (width $\times$ depth $\times$ height) and 8 hens were housed per cage, providing 750 $\mathrm{cm}^{2}$ of total cage area per hen. Layers were assigned to 35 feeding replicates with 2 cages per replicate (yielding 7 replicates per treatment). The duration of the experiment was 40 weeks and it comprised ten 4-week periods. During the trial, the day length was 14.5 hours and the temperature was kept at $20^{\circ} \mathrm{C}$.
\end{abstract}

There were two 20-week feeding phases. In the second feeding phase, the diets had more calcium, better suited to the latter half of the laying phase. The diets within the feeding phases were formulated to contain equal amounts of nutrients per MJ of apparent metabolizable energy (AME) and meet the nutrient requirements of LSL Classic hens (Lohmann 2010). The nutrient content of diets were equalised with rapeseed oil, amino acids, monocalcium phosphate and limestone. The energy values (MJ AME per kg) were based on the feed values of feed ingredients published in the Finnish Feed Tables and Nutrient Requirements (MTT 2014). The processed FB seeds were expanded at $90-110^{\circ} \mathrm{C}\left(5-20\right.$ bar, conditioned at $\left.70-80^{\circ} \mathrm{C}\right)$. All grain ingredients, including FB, were ground in a roller mill (Gehl Company, West Bend, Wisconsin, USA). The feeds were mixed and steam-pelleted (Kahl 33-50, Amandus Kahl GmbH \& Co. KG, Hamburg, Germany). The pellet diameter was $4 \mathrm{~mm}$. In the hen house a chain feeder supplied the feed, and nipple drinker lines supplied water. Feed and water were available ad libitum throughout the experiment.

\section{Analytical and experimental procedures}

Feed samples were taken from every batch made and then pooled. The pooled samples were passed through a hammer mill fitted with a 1-mm mesh for analysis. The crude fat and ash contents were determined by standard methods (AOAC 1990). The crude fibre content was determined with a modified method (AOAC method 962.09) using glass wool instead of a ceramic fiber filter. The nitrogen content was analysed using a Leco FP 428 nitrogen analyser (Leco Corporation, St. Joseph, MI). The crude protein content was calculated by multiplying the nitrogen content by 6.25 . The content of $\mathrm{V}+\mathrm{C}$ in $\mathrm{FB}$ samples was determined using high-performance liquid chromatography (HPLC) according to Quemener (1988).

Egg weight and number were recorded daily, and the mean production variables were calculated for each 4-week period. Mortality was recorded daily. Cumulative mortality was calculated at the end of the experiment. The Finnish Food Safety Authority diagnosed the cause of death and performed autopsies on one hen per replicate euthanized (by cervical dislocation) after experiment. The hens were weighed at the age of 40-, 59-, and 79 weeks.

Egg quality was examined when the birds were 53- and 74 weeks old. The egg quality variables: specific weight, shell strength, Haugh units, and shell thickness were measured in 8 eggs per replicate. The assessment of the specific gravity of eggs was based on Archimedes' principle. The mass of the water $\left(22^{\circ} \mathrm{C}\right)$ displaced by each egg was weighed by placing the egg in a wire basket. The basket was supported from the outside in a water bowl that was on a scale. Specific gravity was calculated as the quotient of the egg mass and the mass of the water displaced by the egg. The shell-breaking force was measured as compressive fracture force using an eggshell tester (OTAL Precision Company Limited, Ottawa, ON, Canada). Albumen height was measured with a digital tripod micrometre (York Electronic Centre, Technical Services and Supplies Limited, York, England) and converted to Haugh units.

\section{Statistical analyses}

Production performance data were subjected to repeated-measures ANOVA using the GLM procedure of SAS (SAS Institute Inc., Cary, NC, USA) and the following model: $Y_{i \mathrm{jk}}=\mu+t_{i}+\delta_{i}+p_{j}+(p \times t)_{i j}+\varepsilon_{i j k}$, where $Y_{i j k}=$ observation, $\mu$ $=$ the general mean, $t_{i}=$ the effect of the treatment $(i=1, \ldots, 5), \delta_{i}=$ the error term for the effect of the treatment $\mathrm{i}, \mathrm{p}_{\mathrm{j}}=$ the effect of the period $(\mathrm{j}=1, \ldots, 10)$, and $\varepsilon_{\mathrm{ijk}}=$ the experimental error term. The egg quality variables and live weight were analysed using the following model: $Y_{i j}=\mu+t_{i}+\varepsilon_{i k^{\prime}}$, where $Y_{i j}=$ observation, $\mu=$ the general mean, $t_{i}$ $=$ the effect of the treatment $(i=1, \ldots, 5)$, and $\varepsilon_{\mathrm{ijk}}=$ the experimental error term. The treatment effects were sepa- 
rated into four orthogonal contrasts as follows: Effect of $F B$, control (SBM) treatment vs. FB treatments; Effect of

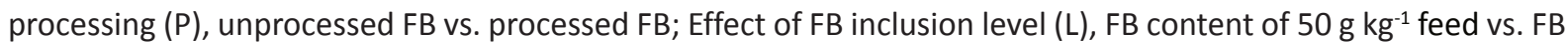
content of $100 \mathrm{~g} \mathrm{~kg}^{-1}$ feed; and the interaction of processing and $F B$ inclusion level $(P \times L)$. In cases where interactions between processing and FB level were noted $(p<0.10)$, the effect were further tested within each four level of the factor (effect of processing at both inclusion level and effect of inclusion level of both FB type). In the current study, $p<0.05$ was considered to be significant and $p<0.10$ tended to be significant.

\section{Results}

Table 1 presents composition and calculated and analysed chemical composition of the experimental diets. The crude protein content of expander-processed FB was lower than that of unprocessed FB (Table 2). The crude protein content of SBM was clearly higher than that of unprocessed or expander-processed faba beans. The $\mathrm{V}+\mathrm{C}$ content in unprocessed and processed FB were similar.

FB inclusion tended to increase the cumulative mortality of hens throughout the entire experiment $(p<0.10)($ Table 3). The mortality of the hens fed unprocessed FB increased with increasing inclusion level $(p<0.05)$, whereas the mortality of hens fed expander-processed FB remained the same. During the latter half of the laying phase the mortality was lower in the unprocessed FB treatments compared with the processed FB treatments $(p<0.01)$.

Based on the amount of abdominal adipose tissue present, the euthanized (one hen per replicate) sample hens were obese and in a few cases hens had fatty livers indicating that hens may have been received too much energy from the experimental diets. All the sample hens were in lay. There was no evidence that the mortality among hens fed by FB was caused by FB inclusion, and no specific reason for mortality was observed among deceased hens.

During the entire and early part of the trial an increase in unprocessed FB inclusion level $\left(50 \mathrm{~g} \mathrm{~kg}^{-1} \mathrm{vs} 100 \mathrm{~g} \mathrm{~kg}^{-1}\right.$ feed) reduced the egg production rate (\%), but the same effect was not observed with expander-processed FB (processing $\times$ inclusion level, $p<0.10$ and $p<0.10$ ). The only significant effect of FB supplementation compared to the control diet was in egg weight $(\mathrm{g})$, which was lower in hens fed diets containing FB during the entire and latter part of the trial $(p<0.05$ and $p<0.01)$. The increase in FB level reduced egg weight with expander-processed FB but not with unprocessed FB during the entire and early part of the trial (processing $\times$ inclusion level, $p<0.05$ and $p<0.05)$. FB had no effect on egg mass production and unprocessed FB only tended to reduce egg mass production during the early part of the trial $(p<0.10)$. Egg mass production (production, g per hen per $\mathrm{d}$ ) decreased when the FB inclusion level increased from 50 to $100 \mathrm{~g} \mathrm{~kg}^{-1}$ feed during the entire $(p<0.01)$, early $(p<0.01)$ and latter $(p<0.10)$ part of the trial. Feed consumption rates ( $\mathrm{g}$ per hen per $\mathrm{d}$ ) were similar in all the treatments. Feed conversion ratio (FCR) ( $\mathrm{g}$ of feed per $\mathrm{g}$ of egg) was impaired when the FB inclusion level increased $\left(50 \mathrm{~g} \mathrm{~kg}^{-1} \mathrm{vs.} 100 \mathrm{~g}\right.$ $\mathrm{kg}^{-1}$ feed) during the entire $(p<0.05)$ and early $(p<0.01)$ part of the trial. FCR of the hens fed unprocessed FB was lower than that of the hens fed processed FB during the early part of the trial $(p<0.05)$. Increase in FB inclusion level ( $50 \mathrm{~g} \mathrm{~kg}^{-1}$ vs. $100 \mathrm{~g} \mathrm{~kg}^{-1}$ feed) increased FCR with unprocessed FB but not with expander-processed FB during the latter part of the trial (processing $\times$ inclusion level, $p<0.10$ ). The egg quality variables studied (specific weight, shell strength, Haugh units, and shell thickness) were similar in all the treatments (Table 4). Dietary treatments had no effects on hen live weights (data not shown).

Table 2. Analysed chemical composition of soybean meal and unprocessed and expander-processed FB ( $\mathrm{g} \mathrm{kg}^{-1}$ of DM), except DM ${ }^{1}$.

\begin{tabular}{lccc}
\hline & $\mathrm{SBM}^{2}$ & $\mathrm{FB}^{3}$, unprocessed & $\mathrm{FB}^{3}$, expander-processed \\
\hline DM, g kg ${ }^{1}$ & 887 & 890 & 881 \\
Crude protein & 538.0 & 302 & 285 \\
Crude fat & 26.2 & 22.7 & 21.5 \\
Crude fibre & 43.8 & 93.9 & 95.5 \\
Ash & 70.0 & 37.2 & 48.3 \\
Nitrogen-free extract & 322.0 & 544.2 & 549.7 \\
Vicine and convicine & - & 10.6 & 8.9 \\
\hline
\end{tabular}

${ }^{1}$ based on single analysis DM: dry matter

${ }^{2} \mathrm{SBM}$ : soybean meal

${ }^{3} \mathrm{FB}$ : faba bean 


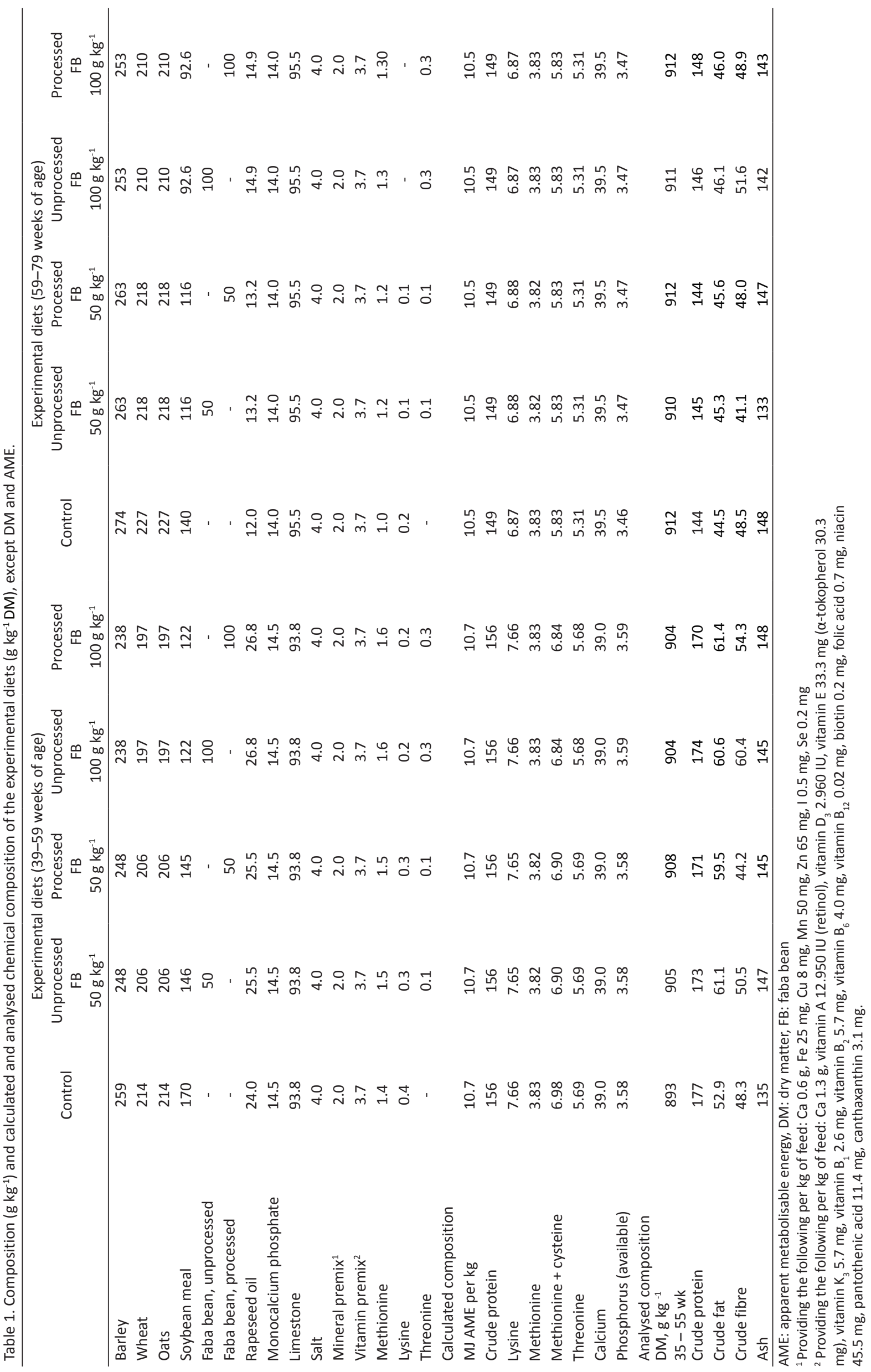


E. Koivunen et al. (2014) 23: 165-172

Table 3. The effects of faba bean dietary inclusion level on laying hen egg production variables.Values are means of 7 observations per treatment and they represent the means of the values of 5 or 10 periods (4 weeks each).

\section{Faba bean inclusion}

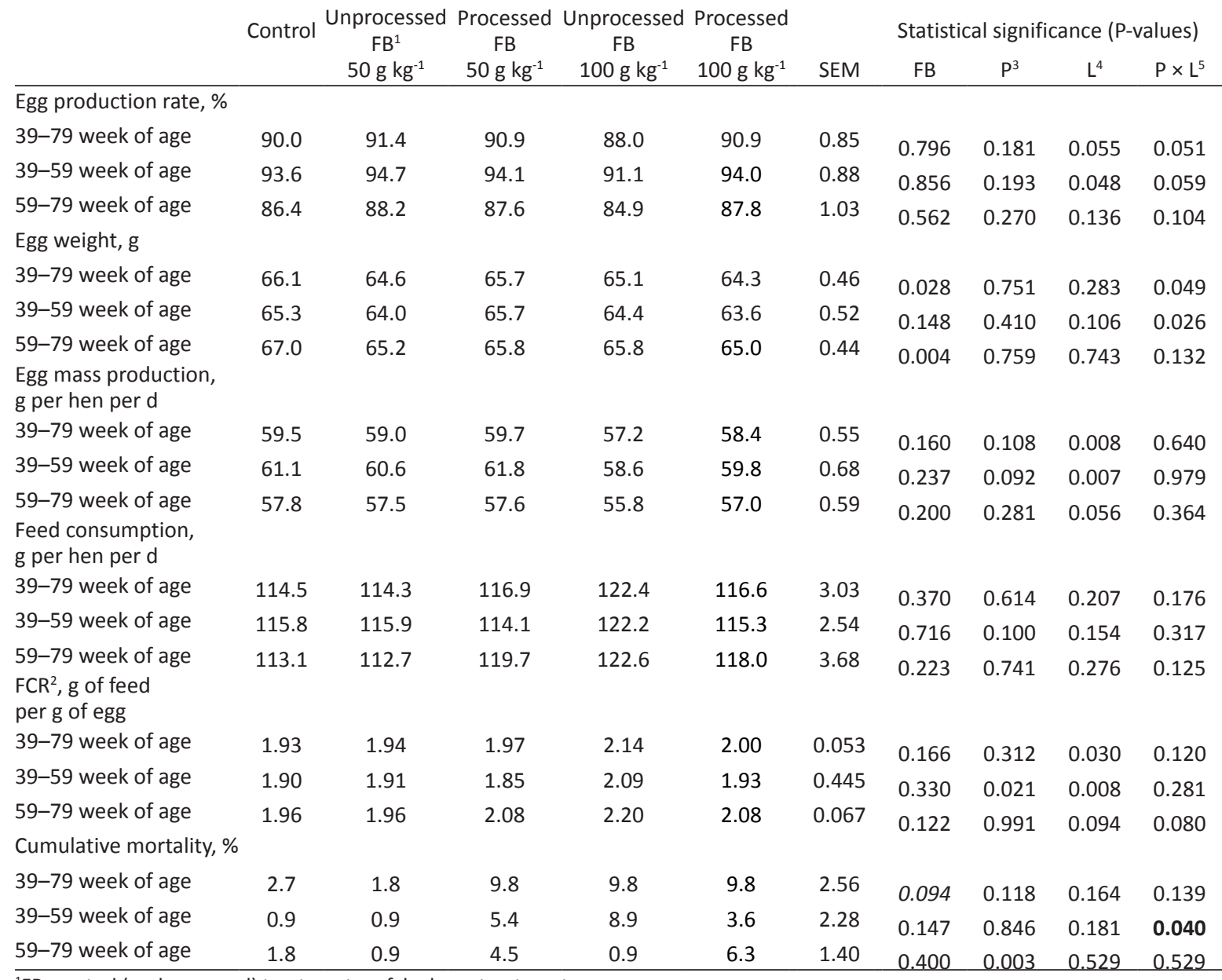

${ }^{1} \mathrm{FB}$ : control (soybean meal) treatment vs. faba bean treatment

${ }^{2} \mathrm{FCR}$ : feed conversion ratio

${ }^{3} \mathrm{P}$ : unprocessed faba beans vs. processed faba beans

${ }^{4} \mathrm{~L}$ : faba bean content $50 \mathrm{~g} \mathrm{~kg}^{-1} \mathrm{vs}$. faba bean content $100 \mathrm{~g} \mathrm{~kg}^{-1}$

${ }^{5} \mathrm{P} \times \mathrm{L}$ : interaction of processing and $\mathrm{FB}$ inclusion level

Table 4. The effects of faba bean dietary inclusion level on laying hen egg quality variables. Values are means of 7 observations per treatment (each observation is a mean of 8 eggs per experimental unit) and represent the mean values.

Faba bean inclusion

$\begin{array}{ccccc}\text { Control Unprocessed Processed Unprocessed Processed } & \text { Statistical significance (P-values) } \\ \mathrm{FB}^{1} & \mathrm{FB} & \mathrm{FB} & \mathrm{FB} & \end{array}$

\begin{tabular}{|c|c|c|c|c|c|c|c|c|c|c|}
\hline & & $50 \mathrm{~g} \mathrm{~kg}^{-1}$ & $50 \mathrm{~g} \mathrm{~kg}^{-1}$ & $100 \mathrm{~g} \mathrm{~kg}^{-1}$ & $100 \mathrm{~g} \mathrm{~kg}^{-1}$ & SEM & $\mathrm{FB}$ & $\mathrm{P}^{2}$ & L & $P \times L^{3}$ \\
\hline \multicolumn{11}{|l|}{ Specific weight } \\
\hline 53 week of age & 1.09 & 1.09 & 1.09 & 1.09 & 1.09 & 0.001 & 0.629 & 0.750 & 0.921 & 0.961 \\
\hline 74 week of age & 1.08 & 1.08 & 1.08 & 1.08 & 1.08 & 0.001 & 0.580 & 0.450 & 0.329 & 0.972 \\
\hline \multicolumn{11}{|l|}{ Shell strength, kg } \\
\hline 53 week of age & 3.77 & 3.71 & 3.87 & 3.78 & 3.66 & 0.085 & 0.892 & 0.812 & 0.452 & 0.110 \\
\hline 74 week of age & 3.31 & 3.13 & 3.05 & 3.17 & 3.04 & 0.151 & 0.218 & 0.507 & 0.907 & 0.875 \\
\hline \multicolumn{11}{|l|}{ Haugh units } \\
\hline 53 week of age & 82.0 & 82.2 & 82.1 & 84.1 & 81.3 & 0.99 & 0.703 & 0.160 & 0.616 & 0.188 \\
\hline 74 week of age & 86.4 & 87.3 & 86.1 & 84.9 & 86.3 & 1.30 & 0.876 & 0.921 & 0.409 & 0.309 \\
\hline \multicolumn{11}{|c|}{ Shell thickness, $\mu \mathrm{m}$} \\
\hline 53 week of age & 387 & 391 & 394 & 389 & 386 & 3.6 & 0.459 & 0.901 & 0.187 & 0.417 \\
\hline 74 week of age & 381 & 376 & 382 & 380 & 381 & 3.4 & 0.830 & 0.325 & 0.812 & 0.513 \\
\hline
\end{tabular}

${ }^{1} \mathrm{FB}$ : control (soybean meal) treatment vs. faba bean treatment

${ }^{2} \mathrm{P}$ : unprocessed faba beans vs. processed faba beans $\mathrm{L}$ : faba bean content $50 \mathrm{~g} \mathrm{~kg}^{-1} \mathrm{vs}$. faba bean content $100 \mathrm{~g} \mathrm{~kg}^{-1}$

${ }^{3} \mathrm{P} \times \mathrm{L}$ : interaction of processing and FB inclusion level 


\section{Discussion}

The crude protein content of the batch of FB studied (unprocessed $302 \mathrm{~g} \mathrm{~kg}^{-1}$ and processed $285 \mathrm{~g} \mathrm{~kg}^{-1}$ ) were similar compared to the table value published in the Finnish Feed Tables and Nutrient Requirements $\left(300 \mathrm{~g} \mathrm{~kg}^{-1}\right.$ for unreported FB cultivar) (MTT 2014). The average rates of starch, crude fibre and crude fat contents ( $\mathrm{g} \mathrm{kg}^{-1}$ DM basis) for unreported FB cultivar are 380, 80 and 20 (respectively) (MTT 2014). Considering the major variations in nutrient content detected between and within FB genotypes (Duc et al. 1999), the nutrient content in studied FB cultivar were typical. The 74 genotypes showed wide variations in their main constituents $\left(\mathrm{g} \mathrm{kg}^{-1} \mathrm{DM}\right.$ basis) in the study of Duc et al. (1999): with starch from 370 to 505, protein from 247 to 372, cell walls from 127 to 222 and neutral detergent fibre from 134 to 264,sugars from 35 to 63, ash from 30 to 55 and crude fat from 11 to 47 . The diets in feeding phases were very similar in their content of crude protein. However, even the mild heat treatment $\left(90-110^{\circ} \mathrm{C}\right)$ during expander-processing may had a positive effect on $\mathrm{FB}$ carbohydrate utilization. Lacassagne et al. (1988) have previously reported that heat treatment had a considerable effect on faba bean starch digestibility and energy value.

To our knowledge, no research studies have previously been conducted on the $\mathrm{V}+\mathrm{C}$ content of the FB cultivar used in this study. The $\mathrm{V}+\mathrm{C}$ content detected in this study corresponds with the results of Duc et al. (1999) who reported that $\mathrm{V}+\mathrm{C}$ content in high $\mathrm{V}+\mathrm{C}$ varieties usually ranges from 6 to $14 \mathrm{~g} \mathrm{~kg}^{-1}$ of mature seed $\mathrm{DM}$. The analysed $\mathrm{V}+\mathrm{C}$ content imply that studied FB (cv. 'Kontu') was a V+C containing cultivar, considering that in the study of Jezierny et al. (2010) $\mathrm{V}+\mathrm{C}$ content in low $\mathrm{V}+\mathrm{C}$ genotype was $0.3 \mathrm{~g} \mathrm{~kg}^{-1} \mathrm{DM}$. In the present study, the difference in $\mathrm{V}+\mathrm{C}$ content between unprocessed and expander-processed FB was non-existent. This is in line with previous reports that vicine and convicine are heat-stable compounds and not easily removed by technological or chemical processing (Duc et al. 1999, Dvořák et al. 2006, and Vilariño et al. 2009). In the study of Dvořák et al. (2006), different methods of treatment - including exposure to over $100{ }^{\circ} \mathrm{C}$, to organic acids, and to substrate maturation along with subsequent drying, were tested without any significant effects on the $\mathrm{V}+\mathrm{C}$ content.

In the current study, mortality tended to increase with dietary FB. In the study of Robblee et al. (1977), a FB inclusion level of $200 \mathrm{~g} \mathrm{~kg}^{-1}$ feed had no adverse effect on mortality of white Leghorn pullets, but a level of $300 \mathrm{~g}$ $\mathrm{kg}^{-1}$ feed increased the mortality rate. It is conceivable that the $\mathrm{V}+\mathrm{C}$ content of the studied FB (cv. 'Kontu') may had been higher than that of the FB (cv. 'Ackerperle') used by Robblee et al. (1977), but they did not report the $\mathrm{V}+\mathrm{C}$ content of the cultivar they used. In the study of Fru-Nji et al. (2007) mortality rates were not reported, indicating that FB inclusion had no major problems on the mortality of the hens in their study (half were LSL and the other half Lohmann Brown). In contrast to our study, FB inclusion had no adverse effect on mortality in the studies of Campbell et al. (1980), Perez-Maldonado et al. (1999), and Laudadio and Tufarelli (2010). Campbell et al. (1980) used SCWL laying hens, Hy-line, and FB at $250 \mathrm{~g} \mathrm{~kg}^{-1}$ in the diet. Perez-Maldonado et al. (1999) used SIRO-CB pullets, and FB cv. 'Fiord' at $250 \mathrm{~g} \mathrm{~kg}^{-1}$ in the diet. Laudadio and Tufarelli (2010) used ISA Brown pullets, and FB cv. 'Prothabat' at $240 \mathrm{~g} \mathrm{~kg}^{-1}$ in the diet. According to Crépon et al. (2010) human carriers of a widespread genetic defect, experience FB toxicity: a deficiency of the erythrocyte-located glucose-6-phosphate dehydrogenase (G6PD). To our knowledge, there was no evidence in literature that this genetic defect is also in poultry, but this possibility can't be excluded.

Reduced egg weight related to FB supplementation agrees with the findings of previous studies (Robblee et al. 1977, Campbell et al. 1980, Olaboro et al. 1981). Muduuli et al. (1981) demonstrated that vicine consumption reduced egg weight and increased erythrocyte hemolysis. According to Muduuli et al. (1981) vicine may act in following three ways: reduces the amount of precursor material available to the granulosa cells, by damaging granulose cells and hence their activity, or by destroying the ovum. However, Fru-Nji et al. (2007) reported that increases in dietary FB content seemed to increase albumen fraction and simultaneously reduce the yolk fraction of the eggs. Albumen and yolk weights were not determined in the current study, but the reduction observed in egg weight with dietary FB supplementation might be due to a reduction of the yolk fraction.

Campbell et al. (1980) reported lower egg weight when less methionine was added to FB diets. Davidson et al. (1973) reported that added methionine is beneficial to prevent egg weight loss when FB is used in layer diets. According to Fru-Nji et al. (2007), the reduction in egg mass production during increased dietary FB inclusion may be due to ANF of the FB, and also because of the deficient essential amino acid (methionine and cysteine) content of the FB. In our study, the methionine was supplied to achieve the nutrient requirements of the hens. In the current study the differences in chemical composition of experimental diets or detected feed consumption rates seemed not to be related to egg weight loss or decreased daily egg mass production. Therefore we assumed that the reduction in egg weight observed between the control and the FB diets, and the reduction in daily egg mass production observed between the $50 \mathrm{~g} \mathrm{FB} \mathrm{kg}^{-1}$ feed and the $100 \mathrm{~g} \mathrm{FB} \mathrm{kg}^{-1}$ feed was mainly due to $\mathrm{V}+\mathrm{C}$ and probably not due to different amounts of dietary methionine content. 
In agreement with our results, Robblee et al. (1977), Muduuli et al. (1981), and Fru-Nji et al. (2007) reported no differences in feed consumption between the control and FB diets. In contrast, Laudadio and Tufarelli (2010) reported decreased feed intake, and Magoda and Gous (2011) reported increased feed intake with increased FB inclusion. Magoda and Gous (2011) suggested that the hens needed to consume more feed to meet their nutrient requirements when $\mathrm{FB}$ is included in the diet. In agreement with the study of Fru-Nji et al. (2007), in our study FCR increased with dietary FB inclusion. The results of the current study are consistent with those of Laudadio and Tufarelli (2010), and Magoda \& Gous (2011) reported that dietary FB inclusion had no negative influence on hen body weight.

Faba bean inclusion had no effects on the egg quality variables studied. This agrees with the results of Fru-Nji et al. (2007) (shell strength), Laudadio and Tufarelli (2010) (Haugh unit and shell thickness), and Robblee et al. (1977) (specific weight). In contrast to the current study, in the study of Robblee et al. (1977) the Haugh unit values increased as the amount of FB in laying hen diets increased.

In conclusion, when the diets are balanced with nutrients $50 \mathrm{~g} \mathrm{~kg}^{-1}$ feed of unprocessed or processed $\mathrm{V}+\mathrm{C}$ containing FB (cv. 'Kontu') can be used in laying hen (LSL Classic) diets based on cereals and SBM, without negative effects on the production performance or livability of laying hens. Expander-processing did not reduce the content of $\mathrm{V}+\mathrm{C}$ in $\mathrm{FB}$ and nor did it had an effect on the production performance of the hens.

\section{Acknowledgments}

Hankkija-Maatalous Oy supported this study. The authors would like to thank Outi Karesma, Tapani Ratilainen, and the staff of the Animal Production Laboratory of MTT Agrifood Research Finland for their professional input to this study. Erja Koivunen thanks the Agriculture Research Foundation of August Johannes and Aino Tiura and the Raisio Plc Research Foundation for providing grant to write this publication.

\section{References}

AOAC 1990. Official Methods of Analysis. Association of Official Analytical Chemists, Inc., Arlington, VA. 1298 p.

Brufay, J., Boros, D. \& Marquardt, R.R. 1998. Influence of growing season, tannin content, autoclave treatment on the nutritive value of near-isogenic lines of faba beans (Vicia Faba L.) when fed to leghorn chicks. British Poultry Science 39: 97-105.

Campbell, L.D., Olabora, G., Marquardt, R.R. \& Waddell, D. 1980. Use of faba beans in diets for laying hens. Canadian Journal of Animal Science 60: 395-405.

Crépon K., Marget, P., Peyronnet, C., Carrouée, B., Arese, P. \& Duc, G. 2010. Nutritional value of faba bean (Vicia faba L.) seeds for feed and food. Field Crop Research 115: 329-339.

Davidson, J. 1973. The nutritive value of field beans (Vicia faba L.) for laying hens. British Poultry Science 14: 557-567.

Duc, G., Marget, P., Esnault, R., LeGuen, J. \& Bastianelli, D. 1999. Genetic variability for feeding value of faba bean seeds (Vicia faba L.): comparative chemical composition of isogenics involving zero-tannin and zero-vicine genes. Journal of Agricultural Science 133: 185-196.

Dvořák, R., Pechova, A., Pavlata, L., Klejdus, B., Kovarcik, K., Dostalova, J. Culkova, J.,Filipek, J., Svajdlenka, E. \& Capkova, V. 2006. Reduction in the content of antinutritional substances in fava beans (vicia faba) by different treatments. Slovenian Veterinary Research 43: 174-179. Proc. 7th Middle European Buiatric Congress, Radenci, Slovenia, 29 March-1 April 2006.

Fru-Nji, F., Niess, E. \& Pfeffer, E. 2007. Effect of graded replacement of soybean meal by faba beans (Vicia faba L.) or field peas (Pisum Sativum L.) in rations for laying hens on egg production and quality. Journal of Poultry Science 44: 34-41.

Gatel, F. 1994. Protein quality of legume seeds for non-ruminant animals: a literature review. Animal Feed Science and Technology 45: 317-348.

Jensen, E.S., Peoples, M.B. \& Hauggaard-Nielsen, H. 2010. Faba bean in cropping systems. Field Crops Research 115: $203-216$.

Jezierny, D., Mosenthin, R. \& Bauer, E. 2010. The use of grain legumes as a protein source in pig nutrition. Animal Feed Science and Technology 157: 111-128.

Lacassagne, L., Francech, M., Carré, B., Melcion, J.-P. 1988. Utilixation of tannin-containing and tannin-free faba beans (Vicia faba) by young chicks: effects of pelleting feeds on energy, protein and starch digestibility. Animal Feed Science and Technology 20: 59-68.

Laudadio, V., \& Tufarelli, V. 2010. Treated fava bean (Vicia faba var. minor) as substitute for soybean meal in diet of early phase laying hens: Egg-laying performance and egg quality. Poultry Science 89: 2299-2303.

Lohmann 2010. Layer Management Guide. Lohmann Tierzucht GmbH, Cuxhaven, Germany.

Magoda, S.F. \& Gous, R.M. 2011. Evaluation of dehulled faba bean (Vicia faba cv. Fiord) as a protein source for laying hens. South African Journal of Animal Science 41: 87-93.

Marquardt, R.R. \& Campbell, L.D. 1973. Raw and autoclaved faba beans in chick diets. Canadian Journal of Animal Science 53: 741-746. 
Muduuli, D.S., Marquardt, R.R. \& Guenter, W. 1981. Effect of dietary vicine on the productive performance of laying chickens. Canadian Journal of Animal Science 61: 757-764.

MTT 2014. Feed tables and nutrient requirements. Jokioinen: MTT Agrifood Research Finland. http://www.mtt.fi/feedtables. Accessed 14 January 2014.

Olaboro, G., Campbell, L.D., \& Marquardt, R.R. 1981. Influence of faba bean fractions on egg weight among laying hens fed test diets for a short time period. Canadian Journal of Animal Science 61: 751-755.

Perez-Maldonado, R.A., Mannion, P.F. \& Farrell, D.J. 1999. Optimum inclusion of field peas, faba beans, chick peas and sweet lupins in poultry diets. I. Chemical composition and layer experiments. British Poultry Science 40: 667-673.

Quemener, B. 1988. Improvements in the high performance liquid chromatographic determination of amino sugars and a-galactosides in faba bean, lupine and pea. Journal of Agriculture and Food Chemistry 36: 754-759.

Robblee, A.R., Clandinin, D.R., Hardin, R.T., Milne, G.R. \& Darlington, K. 1977. Studies on the use of faba beans in rations for laying hens. Canadian Journal of Animal Science 57: 421-425.

Vilariño, M., Mètayer, J.P, Crèpon, K. \& Duc, G. 2009. Effects of varying vicine, convicine and tannin contents of faba bean seeds (Vicia faba L.) on nutrition values for broiler chicken. Animal Feed Science and Technology 150: 114-121. 